\title{
Isolated bitemporal hemianopsia due to traumatic chiasmal syndrome
}

\author{
Bulent Yazici, M.D., Sertac Argun Kivanc, M.D.
}

Department of Ophthalmology, Uludağ University Faculty of Medicine, Bursa, Turkey

\begin{abstract}
A 20-year-old man presented with complaints of inability to see the outer half of objects and blurred near vision while reading. His complaints began one year ago after a motor vehicle accident that caused cranio-orbital fractures. Ocular examination revealed complete bitemporal hemianopsia and slight exotropia. Central visual acuity was 20/20 in both eyes. Radiologic studies demonstrated fractures in the fronto-ethmoid and sphenoid bones and thinning of the optic chiasm. No hypothalamic-pituitary abnormality was detected. Clinical findings remained unchanged during follow-up. Although rare, blunt head trauma may cause an isolated damage to the chiasmal crossing nerve fibers, resulting in a complete, bitemporal hemianopsia associated with normal visual acuity. Traumatic chismal syndrome should be considered in the differential diagnosis of patients presenting with bitemporal hemianopsia.
\end{abstract}

Keywords: Bitemporal hemianopsia; head trauma; optic chiasmal injury; traumatic chiasmal syndrome.

\section{INTRODUCTION}

Bitemporal hemianopsia is a sign that typically indicates an optic chiasmal involvement, mostly caused by a compressive tumor. ${ }^{[1]}$ Traumatic chiasmal injury, also called traumatic chiasmal syndrome (TCS), is a rare phenomenon and can manifest with a variety of visual defects. ${ }^{[2]}$ Herein, it was aimed to report a case of TCS with an isolated, complete bitemporal hemianopsia following a traffic accident and review the relevant literature. To the best of our knowledge, this is the first case report of TCS from Turkey.

\section{CASE REPORT}

A 20-year-old man presented with complaints of inability to see the outer half of the objects when looking with only one eye and blurred vision while reading. His complaints had started one year ago after an automobile accident. On ad-

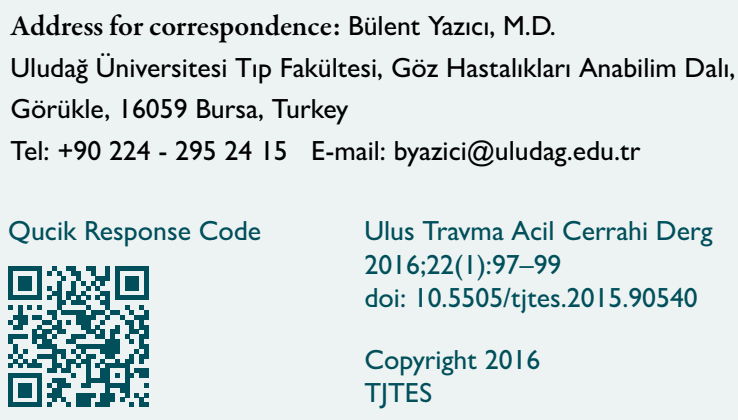

mission to an emergency clinic, he was conscious and complained of blurred vision, and bilateral periorbital ecchymosis was noted. Computed tomography showed frontal, ethmoid, and maxillary fractures in the right orbit, fractures in the sellar region of the sphenoid bone, and air in the orbit and cranium (Fig. Ia). Thirteen days later, frontal craniotomy and cerebrospinal fluid fistula repair were performed for prolonged rhinorrhea and pneumocephalus. After he was discharged from the hospital, the patient underwent an automated 30-2 visual field test because of his visual complaints, and a bitemporal hemianopsia was found.

On examination in our clinic, visual acuities in both eyes were 20/20. A 10-prism diopter exotropia with predominantly right eye fixation was noted in primary position. Other ocular findings were normal. Automated 30-2 visual field test showed a complete bitemporal hemianopsia with macular splitting (Fig. 2). Partial sparing was noted in the macular visual field in the right eye using 10-2 and Amsler grid tests, but the left side showed complete splitting (Fig. 2). Compared with the 30-2 test performed in the previous year, no remarkable change was seen in the current visual field test.

Magnetic resonance imaging showed thinning, shape deformity, and high T2 signal intensity in the optic chiasm (Fig. Ib). Endocrinology consultation found no abnormality in hypothalamic-pituitary functions. The clinical findings were stable during a follow-up of 9 months. 

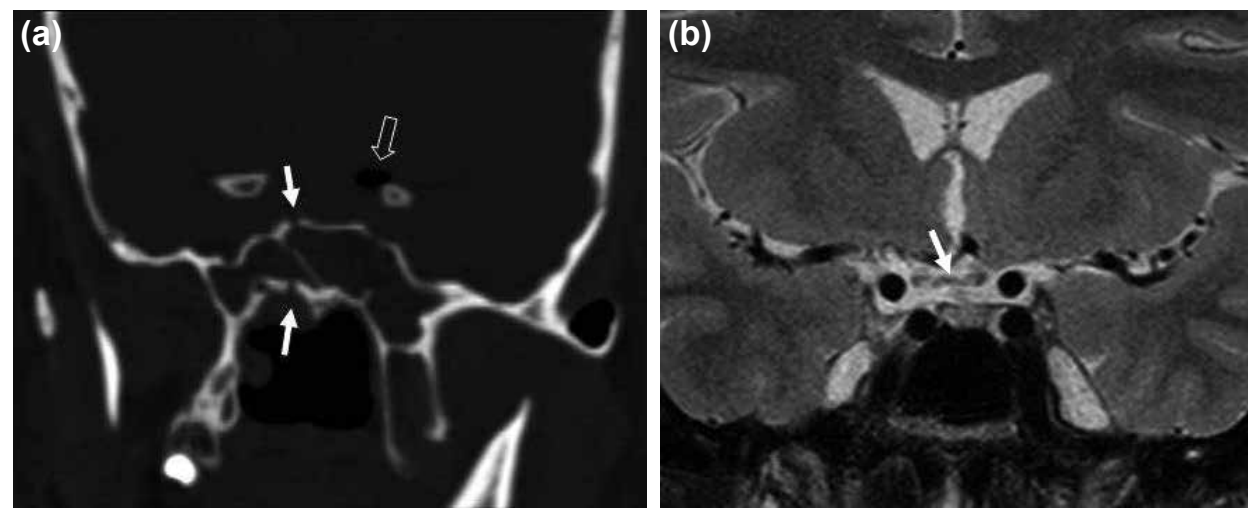

Figure 1. (a) Coronal computed tomography scan with bone window setting at the level of the sella turcica shows fractures (arrows) of the roof and floor of the sphenoid sinus. Intracranial air collection also occurs (open arrow). (b) Coronal T2-weighted magnetic resonance imaging scan obtained 1 year after the accident shows abnormally thin optic chiasm with heterogeneous hyperintensity (arrow).
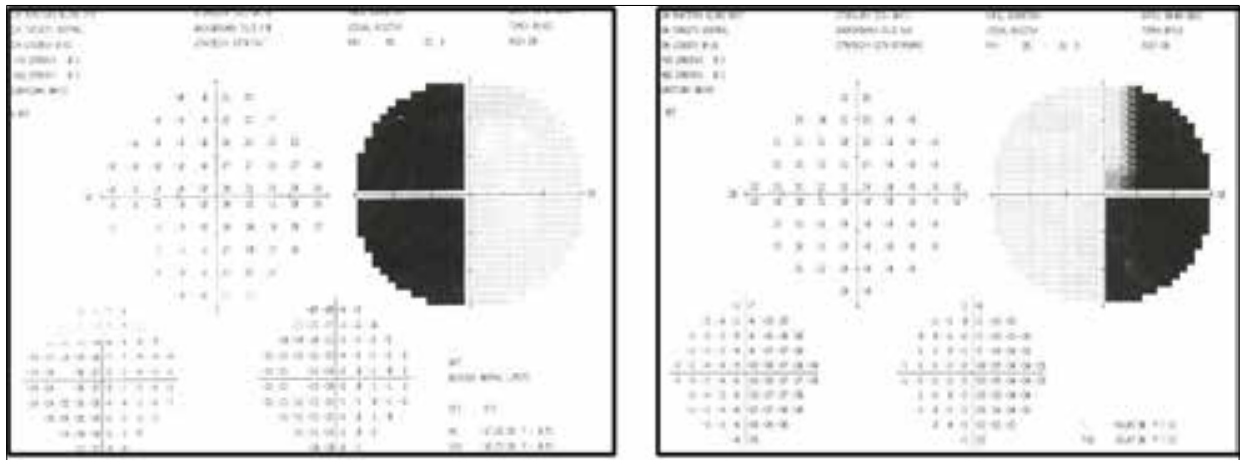

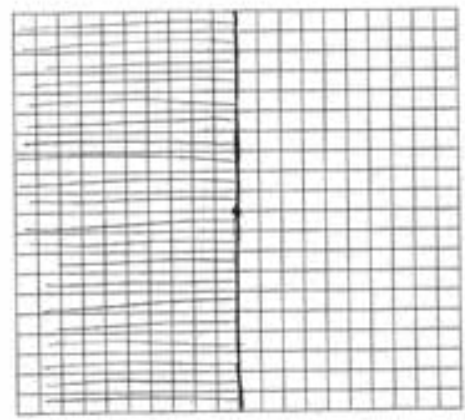

Left Eye

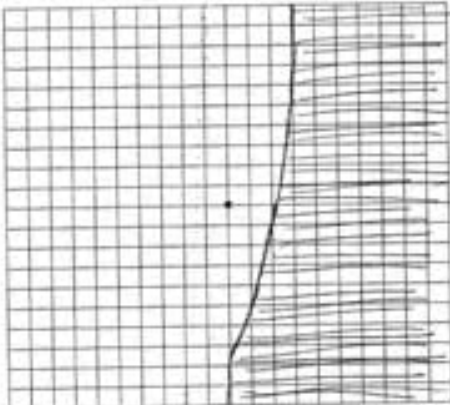

Right Eye

Figure 2. Automated 30-2 and Amsler grid tests showing temporal hemianopsia, which split the macular vision in the left eye, but spared the right side.

\section{DISCUSSION}

Bitemporal hemianopsia, depending on the site and extent of chiasmal damage, may be complete or partial, central or peripheral, and absolute or relative. The temporal visual loss may spare or split the central macular field. Moreover, central visual acuity may remain stable or decrease. The most frequent cause of bitemporal hemianopsia is tumors. One study has reported pituitary adenoma $(60 \%)$ or parasellar tumors $(29 \%)$ in $89 \%$ of 149 patients with bitemporal hemianopsia. ${ }^{[1]}$

Head traumas frequently affect the intracanalicular segment of the optic nerve in the retrobulbar optic pathways. Trau- matic chiasmal injury is rare, and usually occurs in young men and in association with traffic accidents or falls. ${ }^{[3]}$ Frontal and/or basilar fracture is seen in about $70 \%$ of the patients and closed head trauma in $30 \% .^{[4]}$ In the latter group, TCS is frequently associated with an intracranial hematoma. Other accompanying disorders may include cranial nerve palsies (anosmia, hearing loss, optic neuropathy, ocular motor palsy), cerebrospinal fluid leakage, pneumocephalus, meningitis, carotid aneurysm, carotid-cavernous fistula, nystagmus, and hormonal deficiencies. ${ }^{[2]}$

Traumatic chiasmal syndrome is usually diagnosed, as in our patient, after neurologic rehabilitation, when the patient is 
able to undergo a visual field test. As seen in our patient, complete bitemporal hemianopsia with a normal visual acuity is rare..$^{[5,6]}$ In most instances, the prechiasmal optic pathways are also involved. Visual acuity decreases to $20 / 40$ or less in one or two eyes in about $85 \%$ of the patients, and total blindness in one eye occurs in about $50 \%$ of patients. ${ }^{[2,4]}$ In the latter group, temporal hemianopsia is found in the sighted eye. Due to the close proximity of the cavernous sinus, the ocular motor nerves may also be injured. One study has reported paralytic strabismus in $63 \%$ of the patients with TCS. ${ }^{[4]}$ Permanent or transient diabetes insipidus develops in $30 \%$ to $50 \%$ of the patients, resulting from associated hypothalamicpituitary trauma. ${ }^{[2,4]}$ In eyes with midline hemianopsia, the central macular visual field can be evaluated more sensitively by automated 10-2 or Amsler grid visual field tests. Bitemporal visual loss may cause blurred near vision, diplopia, and reading difficulty because of "hemifield slide phenomenon" and preexisting small and latent strabismus may become manifest. ${ }^{\left[{ }^{[]}\right.}$

A bitemporal hemianopsia can occur in the case of damage involving only the crossing of nasal nerve fibers through the midline of the chiasm. It is unclear why compressive lesions show a predilection for damage to the crossing fibers. Vascular theory suggests that a bitemporal hemianopsia results from compression of the inferior group of vessels supplying the crossing fibers of the chiasm. According to a mechanical theory, an expanding mass below the optic chiasm exerts a higher intrinsic pressure in the central aspect of the chiasm than the temporal aspect. ${ }^{[7]}$ It is more surprising that a sudden, blunt trauma may also produce a preferential and precise damage within the chiasm, as in tumoral compression. Several mechanisms have been suggested to explain TCS, such as direct tearing, external compression by brain tissue or hematoma, traumatic thrombosis of supplying arteries, or contusion necrosis. ${ }^{[2]}$ Infrequently, magnetic resonance imaging may display a rupture of the optic chiasm. ${ }^{[4,8]}$ Radiologic findings did not show macroscopic disruption or external compression in the current case. When the optic nerve is displaced posteriorly by the impact, the crossing fibers may be subject to relatively greater pressures and microscopic tears. ${ }^{[9]}$

Currently, there is no management guideline for TCS. Although systemic corticosteroids have been used in some cases, its benefit has not been shown. ${ }^{[2,4]}$ In patients who have received long-term follow-up care, progressive loss or improvement of vision has not developed. Although rare, blunt head trauma may cause an isolated damage to the crossing nerve fibers in the optic chiasm, producing a complete, bitemporal hemianopsia without central visual acuity loss. Traumatic chiasmal syndrome should be considered in the differential diagnosis in patients presenting with bitemporal hemianopsia.

\section{Conflict of interest: None declared.}

\section{REFERENCES}

1. Mejico LJ, Miller NR, Dong LM. Clinical features associated with lesions other than pituitary adenoma in patients with an optic chiasmal syndrome. Am J Ophthalmol 2004;137:908-13.

2. Savino PJ, Glaser JS, Schatz NJ. Traumatic chiasmal syndrome. Neurology 1980;30:963-70.

3. McCann JD, Seiff S. Traumatic neuropathies of the optic nerve, optic chiasm, and ocular motor nerves. Curr Opin Ophthalmol 1994;5:3-10.

4. Hassan A, Crompton JL, Sandhu A. Traumatic chiasmal syndrome: a series of 19 patients. Clin Experiment Ophthalmol 2002;30:273-80.

5. Resneck JD, Lederman IR. Traumatic chiasmal syndrome associated with pneumocephalus and sellar fracture. Am J Ophthalmol 1981;92:233-7.

6. Chirapapaisan N, Sadun AA. A traumatic bitemporal hemianopia with macular sparing. J Med Assoc Thai 2005;88 Suppl 9:126-30.

7. Kosmorsky GS, Dupps WJ Jr, Drake RL. Nonuniform pressure generation in the optic chiasm may explain bitemporal hemianopsia. Ophthalmology 2008;115:560-5.

8. Segal L, An JA, Gans M. Traumatic disruption of the optic chiasm. J Neuroophthalmol 2009;29:308-10.

9. McIlwaine GG, Carrim ZI, Lueck CJ, Chrisp TM. A mechanical theory to account for bitemporal hemianopia from chiasmal compression. J Neuroophthalmol 2005;25:40-3.

\section{OLGU SUNUMU - ÖZET}

\section{Travmatik kiyazmal sendroma bağlı izole bitemporal hemianopsi}

\section{Dr. Bülent Yazıcı, Dr. Sertaç Argun Kıvanç}

Uludağ Üniversitesi Tıp Fakültesi, Göz Hastalıkları Anabilim Dalı, Bursa

Yirmi yaşında, erkek hasta her iki gözünde nesnelerin yarısını görememe ve okurken bulanık görme yakınmalarıyla başvurdu. Hastanın yakınmaları bir yıl önce kranyo-orbital kırıklara yolaçan bir trafik kazasından sonra başlamışı. Göz muayenesinde total bitemporal hemianopsi ve hafif ekzotropya saptandı. Görme keskinlikleri her iki gözde I.0'dı. Radyolojik incelemede fronto-etmoid ve sfenoid kemiklerde kırıklar ve optik kiyazmada incelme saptandı. Hipotalamo-hipozifer bir bozukluk saptanmadı. İzlem sırasında görsel bulgularda değişiklik olmadı. Nadir olmakla birlikte, künt kafa travması kiyazmal çaprazlaşan sinir demetlerinde izole bir hasara ve buna bağlı olarak normal görme keskinliğinin eşlik ettiği bir bitemporal hemianopsiye yol açabilir. Travmatik kiyazmal sendrom bitemporal hemianopsinin ayıııcı tanısında göz önünde tutulmalıdır.

Anahtar sözcükler: Bitemporal hemianopsia; kafa travması; optik kiyazmal yaralanma; travmatik kiyazmal sendrom.

Ulus Travma Acil Cerrahi Derg 2016;22(I):97-99 doi: 10.5505/tjtes.2015.90540 